(c) School of Environmental Sciences, Modibbo Adama University of Technology, Yola - Nigeria. ISSN: 1597-8826. http://dx.doi.org/10.4314/fje.v7i1.2

\title{
DETERMINATION OF LAND SURFACE TEMPERATURE (LST) AND POTENTIAL URBAN HEAT ISLAND EFFECT IN PARTS OF LAGOS STATE USING SATELLITE IMAGERIES
}

\author{
Nwilo P. C., Olayinka D. N., Obiefuna J., \\ Atagbaza A. O. and Adzandeh A. E.
}

Department of Surveying and Geoinformatics, University of Lagos, Lagos - Nigeria.

\begin{abstract}
Temperature is an important component of the climate. The temperature of a developing city or state is constantly changing. The trend in temperature change in Nigeria is not consistent. Changes in temperature appear to be closely related to concentrations of atmospheric carbon dioxide. The degree of concentration depends on human interventions and the amount of sunlight reaching the earth's surface. Lagos State particularly in recent time has experienced decrease in vegetation and water pervious surfaces, which reduces surface temperature through evapotranspiration. This is as a result of rapid urbanization arising from inundating rural-urban migration. One of the implications is that anthropogenic heat is released to the environment due to energy consumption and increased impervious surface coverage thereby increasing the surface and atmospheric temperatures. LandSat Satellite imageries have been used to estimate Land Surface Temperature (LST) and urban thermal conditions. The mean LST result shows that, there is a significant increase in the temperature values from 1984 to $2002\left(28.40^{\circ} \mathrm{C}-28.86^{\circ} \mathrm{C}\right)$. However, in 2006 the temperature decreases significantly to $28.37^{\circ} \mathrm{C}$ below 2002 temperatures in all LGAs. This variation could be attributed to the economic crisis/power outage in Nigeria which left manufacturing companies out of production/manufacturing between 2002 and 2006. Findings from this study reveals that there is a relationship between the surface temperature and the various Land Cover types. It shows a broad classification of the Land Cover types into Water bodies, Vegetation and Built-up areas respectively. With the spatial resolution and temporal coverage of two Landsat data of the environment, the derivation of the temperature information was achieved.
\end{abstract}

KEYWORDS: Land Surface Temperature, Landuse/Landcover, Heat Island, Lagos State, Spectral Radiance, Satellite Imageries

\section{Introduction}

Satellite images have many applications in meteorology, agriculture, geology, forestry, biodiversity conservation, regional planning, education, intelligence, warfare and temperature determination to mention a few. Images can be in visible colors and in other spectra. There are also elevation maps, usually made by radar imaging. Interpretation and analysis of satellite imagery are conducted using software packages like ERDAS Imagine or ENVI (Environment for Visualizing Imageries). Satellite imagery is also used in seismology and oceanography in deducing changes to land formation, water depth and sea bed, by color caused by earthquakes, volcanoes, and tsunamis (Lovholt et al., 2006).

In recent time, researches have explored satellite data in land surface temperature derivation. David (2008) used Landsat TM data to estimate temperatures from a fire at the Chernobyl nuclear power plant. His result detected shortwave length infrared thermal radiance which was interpreted to come from sources at around 1130-1430 K. A new range of distribution of temperatures of the hottest visible material was suggested. A comparative study of Land Surface Temperature (LST) over parts of the 
Singhbhum Shear Zone in India was undertaken using various emissivity and temperature retrieval algorithms applied on visible and near infrared (VNIR) and thermal infrared (TIR) bands of high resolution Landsat-7 ETM+ imagery. Minimum LST observed over dense forest was about $26{ }^{\circ} \mathrm{C}$ and maximum LST observed over rock body about $38{ }^{\circ} \mathrm{C}$. The estimated LST showed that rock bodies, bare soils and built-up areas exhibit higher surface temperatures, while water bodies, agricultural croplands and dense vegetations have lower surface temperatures during the daytime (Srivastava et. al., 2009). Strong correlation was found between LST and spectral radiance of Band 6 of Landsat-7 ETM +. Jiansheng and Wang (2009) modelled surface temperature and brightness temperature in southeast New England by adding surface emissivity derived from the conventional image classification with solar zenith angle. Mustard et al. (1999) quantified thermal effluent impact using satellite data. The findings of that study reveals that Mount Hope Bay had anomalously high temperatures throughout the year in the upper estuary and was on average $0 \cdot 8^{\circ} \mathrm{C}$ warmer than the rest of the upper estuary which was implicated in a large decline in fish population in the environment. The total area affected is $36 \mathrm{~km}^{2}$. Javed et al. (2008) estimated land surface temperature over Delhi using Landsat-7 ETM+ and observed a strong correlation between surface temperature with Normalized Difference Vegetation Index (NDVI) over different LU/LC classes. Sobrino et al., (2004) used three methods to retrieve LST from thermal infrared data supplied by band 6 of the Thematic Mapper (TM) (sensor on board the Landsat5 satellite). The first was the estimation of the land surface temperature from the radioactive transfer equation using in-situ radio sounding data. The other two were the mono-window algorithm developed by Qin et al (2001). Thermal remote sensing methodology was explored in studies carried out by Voogt and Oke (2003), Gallo et al. (1993), Carson et al. (1994), Balling and Brazell (1988). Further studies have been conducted in converting Landsat TM and ETM + thermal bands to temperature.

\section{Justification for the Study}

Lagos is regarded as one of the fastest growing urban agglomerations in the world (Millington et al., 2006). The temperature of Lagos State is changing and there is no detailed and original work on LST using Satellite imageries in the area. The temperature change has strong impact on the environment, economy, agriculture, hydrology, and bio-geo-chemical. This study is necessary to estimate LST and to gain knowledge of temperature variations across the State. Urban Sprawl in the city has lead to replacement of vegetal cover by residential buildings, industries and impervious surfaces. All these and climate change scenarios are believed to have impact on temperature of Lagos State. A study of this nature, will serve for further research, planning and environmental sustainability.

\section{The Study Area}

The study area is Lagos State and is situated in the southwest of Nigeria; this elongated state spans the Guinea coast of the Atlantic Ocean for over 180km, from the Republic of Benin on the west to its boundary with Ogun state in the east. It extends approximately from latitude $6^{\circ} 2^{\prime}$ North to $6^{\circ} 4^{\prime}$ North, and from longitude $2^{\circ} 45^{\prime}$ East to $4^{\circ} 20^{\prime}$ East. The administrative boundary of Lagos State is shown in Figure 1. Lagos has a total coverage area of $3,577 \mathrm{~km}^{2}$ of which about $787 \mathrm{sq}$. $\mathrm{km}$ or 22 percent is water. Lagos 
State is ranking as the second most populous city in Africa. UN (2007) reported that the city has a population of 9.5 million.

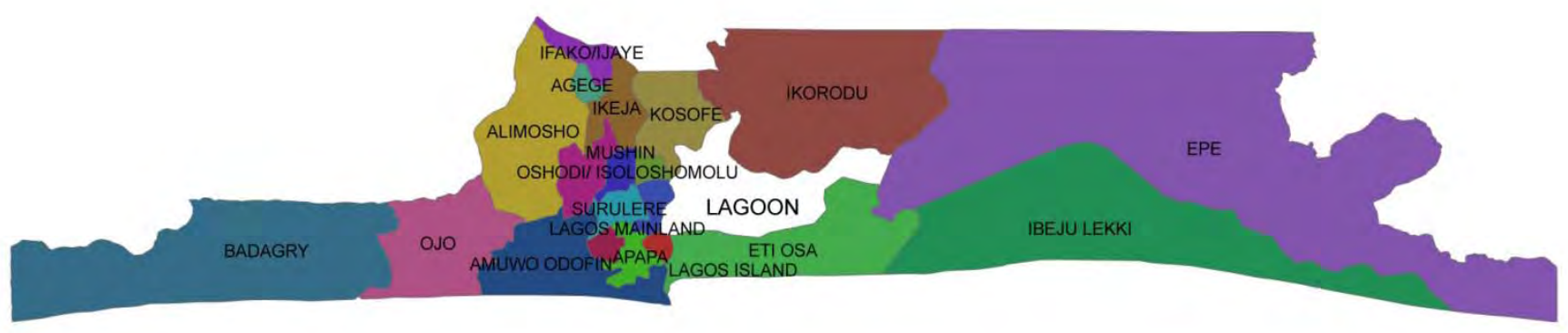

Figure 1: Administrative boundary of Lagos State

\section{Materials and Methods Materials:}

A subset of Landsat TM acquired on December 18, 1984 and December 27, 2002; and a subset of Landsat ETM of December 28, 2006 all with a satellite pass of path 191 and row 55 that covers some parts of Lagos State were used in this study. Figure 2 is a Landsat data of the environment showing study area boundary. Both Landsat TM and ETM have $30 \mathrm{~m}$ spatial resolution at the visible and near infrared spectral region(10.4$12.5 \mu \mathrm{m})$. However, at the thermal infrared spectral region, they differ with TM having $120 \mathrm{~m}$ and ETM having $60 \mathrm{~m}$ spatial resolution respectively. Landsat ETM has enhancements with two bands at the thermal infrared region (Band $6_{1} \& 6_{2}$ ). These bands are in two gain states, one with a high and the other with a low gain both having $60 \mathrm{~m}$ spatial resolution. The imageries were acquired through the USGS Earth Resource Observation Systems Data Centre, which has corrected the radiometric and geometrical distortions of the images to a quality level of $1 \mathrm{G}$ before delivery. Three software packages were used to classify and to complete the processing and analysis namely: ENVI 4.8, IDL 8.0 and ARCGIS 9.3.

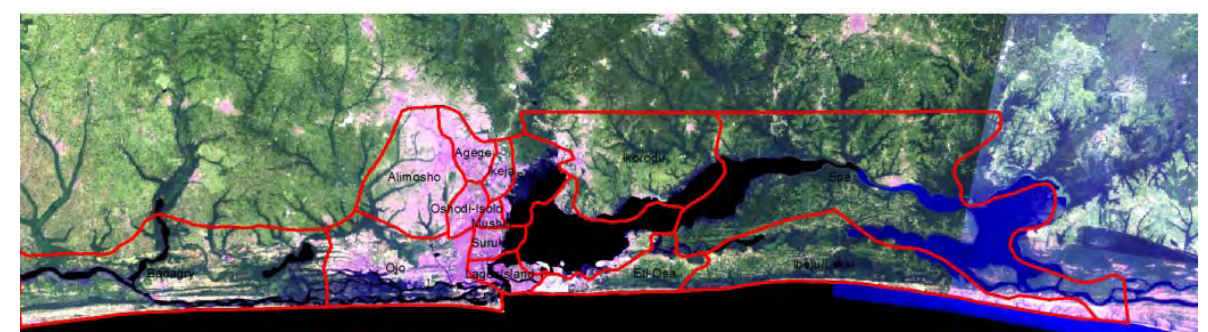

Figure 2: LandSat ETM showing the boundary of Lagos State

\section{Methods}

Several processing steps were carried out in order to classify the LandCover and determine the surface temperature on the imageries. The ENVI software was used to classify the LandCover, IDL was used to process the surface temperature from the image and then classified in ENVI, and ARCGIS 9.3 was used to analyze the data and map creation. In the Land Cover classification, a band sequence of 5,4,3 was used to produce a composite multi-spectral imagery which was used to classify the imagery. An 
unsupervised classification of the imagery using the K-means method was carried out for three classes. The classes are Built-up, Vegetation and Water bodies.

For surface temperature determination, the thermal bands of the imageries were used for the analysis. Weng et al. (2004) described steps to be followed in determining surface temperature. The first step is to process the data by converting the DN(Digital Numbers) to radiance. The radiance is calculated using the equation:

$$
C V_{R}=G\left(C V_{D N}\right)+B
$$

where:

$C V_{R}$ is the cell value as radiance

$\mathrm{CV}_{\mathrm{DN}}$ is the cell value digital number

$\mathrm{G}$ is the gain

$B$ is the bias (or offset)

The next step is to convert the spectral radiance to satellite brightness temperature (i.e., blackbody temperature, TB) under the assumption of uniform emissivity (Landsat Project Science Office, 2002). The conversion formula is:

$$
T B=\frac{K_{2}}{\ln \left(\frac{K_{1}^{*} \varepsilon}{C V_{R}}+1\right)}
$$

where:

$\mathrm{T}_{\mathrm{B}}$ is in degrees Kelvin; $C V_{R}$ is the cell value as radiance; e is emissivity (typically 0.95 ) $\mathrm{K}_{1}=607.76$ for Landsat TM and 666.09 for Landsat ETM; $\mathrm{K}_{2}=1260.56$ for Landsat TM and 1282.71 for Landsat ETM

Finally, the conversion of brightness temperature (Тв) to Land Surface Temperature is performed with Artis and Carnahan, (1982) models. The equation is given thus:

$$
S_{t}=\frac{T_{B}}{1+\left(\lambda \times T_{B} / \rho\right) \ln \varepsilon}
$$

$\lambda$ is wavelength of emitted radiance $(\lambda=11.5 \mu \mathrm{m})$ (Markham \& Barker, 1985)

$\rho=h^{*} \mathrm{c} / \sigma\left(1.438 * 10^{-2} \mathrm{mK}\right)$,

$\sigma=$ Boltzman constant $\left(1.38 * 10^{-23} \mathrm{~J} / \mathrm{K}\right)$,

$\mathrm{h}=$ Planck's constant $\left(6.626^{*} 10^{-34} \mathrm{Js}\right)$, and

$\mathrm{c}=$ velocity of light $\left(3.0 * 10^{8} \mathrm{~m} / \mathrm{s}\right)$

$\varepsilon=0.95$

These equations were programmed in the script in the IDL software. Radiance values were extracted from the thermal band of the imagery and keyed into the program thus generating the temperature values in degrees Celsius. A table was created showing the radiance value with their equivalent temperature value. Thus, for any radiance value generated the temperature value can be automatically derived. This method assumes that all surfaces have an emissivity of 0.95 . A more complete analysis could be done if different emissivities are used for different surfaces. 
Temperature features were extracted across different local government areas. Pixel locator embedded in ENVI software was used to generate points (X,Y coordinates) for selected locations in the study area.

Table 1: Radiance value (pixel number) with the equivalent temperature value

\section{Results and Discussion}

\begin{tabular}{|l|r|r|r|r|r|r|r|r|r|}
\hline $\begin{array}{l}\text { Pixel } \\
\text { No. }\end{array}$ & $\begin{array}{l}\text { Temp. } \\
\left({ }^{\circ} \mathbf{C}\right)\end{array}$ & $\begin{array}{l}\text { Pixel } \\
\text { No. }\end{array}$ & $\begin{array}{l}\text { Temp. } \\
\left({ }^{\circ} \mathbf{C}\right)\end{array}$ & $\begin{array}{l}\text { Pixel } \\
\text { No. }\end{array}$ & $\begin{array}{l}\text { Temp. } \\
\left({ }^{\circ} \mathbf{C}\right)\end{array}$ & $\begin{array}{l}\text { Pixel } \\
\text { No. }\end{array}$ & $\begin{array}{l}\text { Temp. } \\
\left({ }^{\circ} \mathbf{C}\right)\end{array}$ & $\begin{array}{l}\text { Pixel } \\
\text { No. }\end{array}$ & \multicolumn{1}{l}{$\begin{array}{l}\text { Temp. } \\
\left({ }^{\circ} \mathbf{C}\right)\end{array}$} \\
\hline 120 & 19.3522 & 121 & 19.8217 & 122 & 20.2894 & 123 & 20.7553 & 124 & 21.2194 \\
\hline 125 & 21.6818 & 126 & 22.1425 & 127 & 22.6015 & 128 & 23.0587 & 129 & 23.5143 \\
\hline 130 & 23.9683 & 131 & 24.4206 & 132 & 24.8713 & 133 & 25.3204 & 134 & 25.768 \\
\hline 135 & 26.214 & 136 & 26.6584 & 137 & 27.1013 & 138 & 27.5427 & 139 & 27.9826 \\
\hline 140 & 28.421 & 141 & 28.858 & 142 & 29.2935 & 143 & 29.7275 & 144 & 30.1602 \\
\hline 145 & 30.5915 & 146 & 31.0214 & 147 & 31.4498 & 148 & 31.8769 & 149 & 32.3027 \\
\hline 150 & 32.7272 & 151 & 33.1503 & 152 & 33.5721 & 153 & 33.9927 & 154 & 34.4119 \\
\hline 155 & 34.8298 & 156 & 35.2466 & 157 & 35.662 & 158 & 36.0763 & 159 & 36.4893 \\
\hline 160 & 36.9011 & 161 & 37.3117 & 162 & 37.7211 & 163 & 38.1293 & 164 & 38.5364 \\
\hline 165 & 38.9423 & 166 & 39.347 & 167 & 39.7506 & 168 & 40.1531 & 169 & 40.5546 \\
\hline 170 & 40.9548 & 171 & 41.354 & 172 & 41.7521 & 173 & 42.1492 & 174 & 42.5451 \\
\hline 175 & 42.94 & 176 & 43.3339 & 177 & 43.7267 & 178 & 44.1184 & 179 & 44.5092 \\
\hline 180 & 44.899 & & & & & & & & \\
\hline
\end{tabular}

This study has derived temperature and land cover information from LandSat data. From the Maps (Figures 3-5) generated, it is observed that there is a relationship between the surface temperature and the various LandCover types. It shows a broad classification of the LandCover types into Waterbodies, Vegetation and Built-up areas respectively. The built-up areas have the highest temperature range of values because of population growth, human activities like industrialization, deforestation, burning of natural gas, coal and oil which increase the level of $\mathrm{CO}_{2}$ and $\mathrm{CO}$.

These gases are constituents of the green house gases that have been increased and subsequently more infra red radiation trapped and held which gradually increases the temperature of the earth's surface and the air in the lower atmosphere and causes global warming. It is also observed that the wetlands and water body share the same range of temperature which perhaps could be due largely to the fact that wetlands play an important role in the regulation of global climate by sequestering and releasing significant amounts of carbon. 


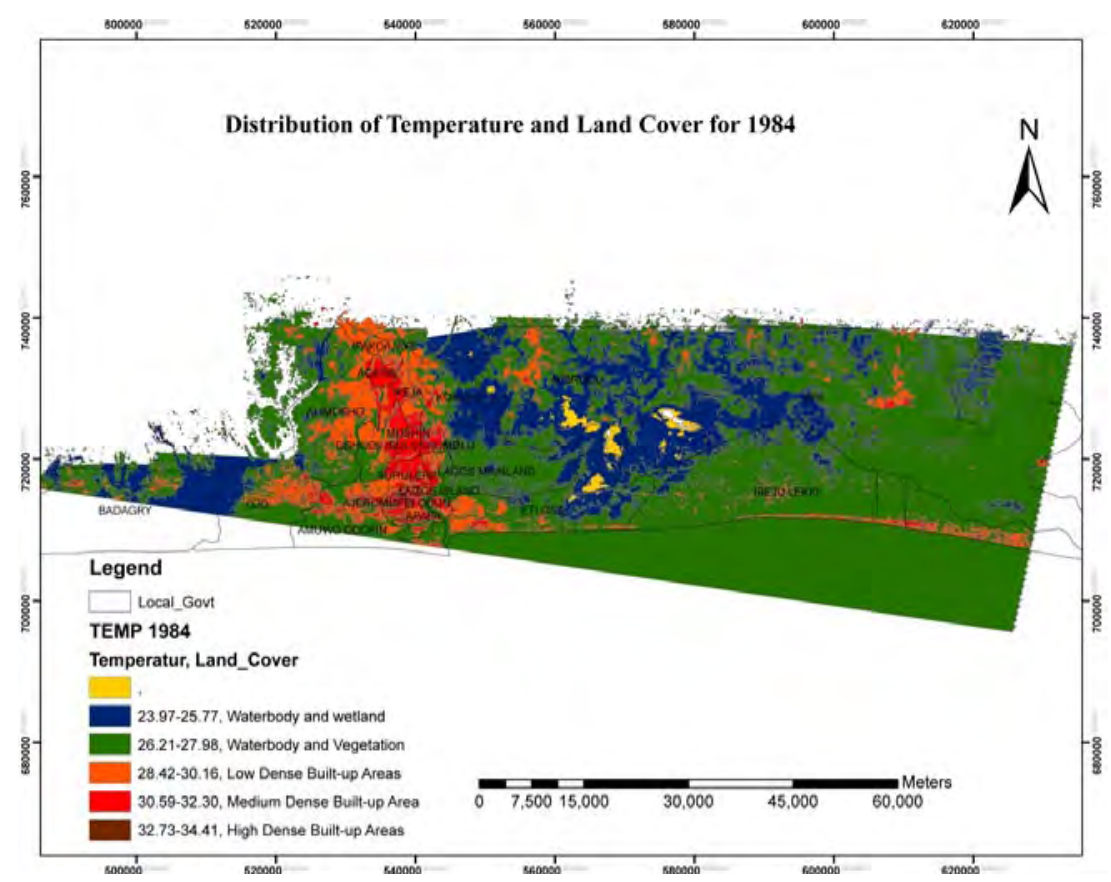

Figure 3: The relationship between the temperature and Land Cover over the Lagos for 1984

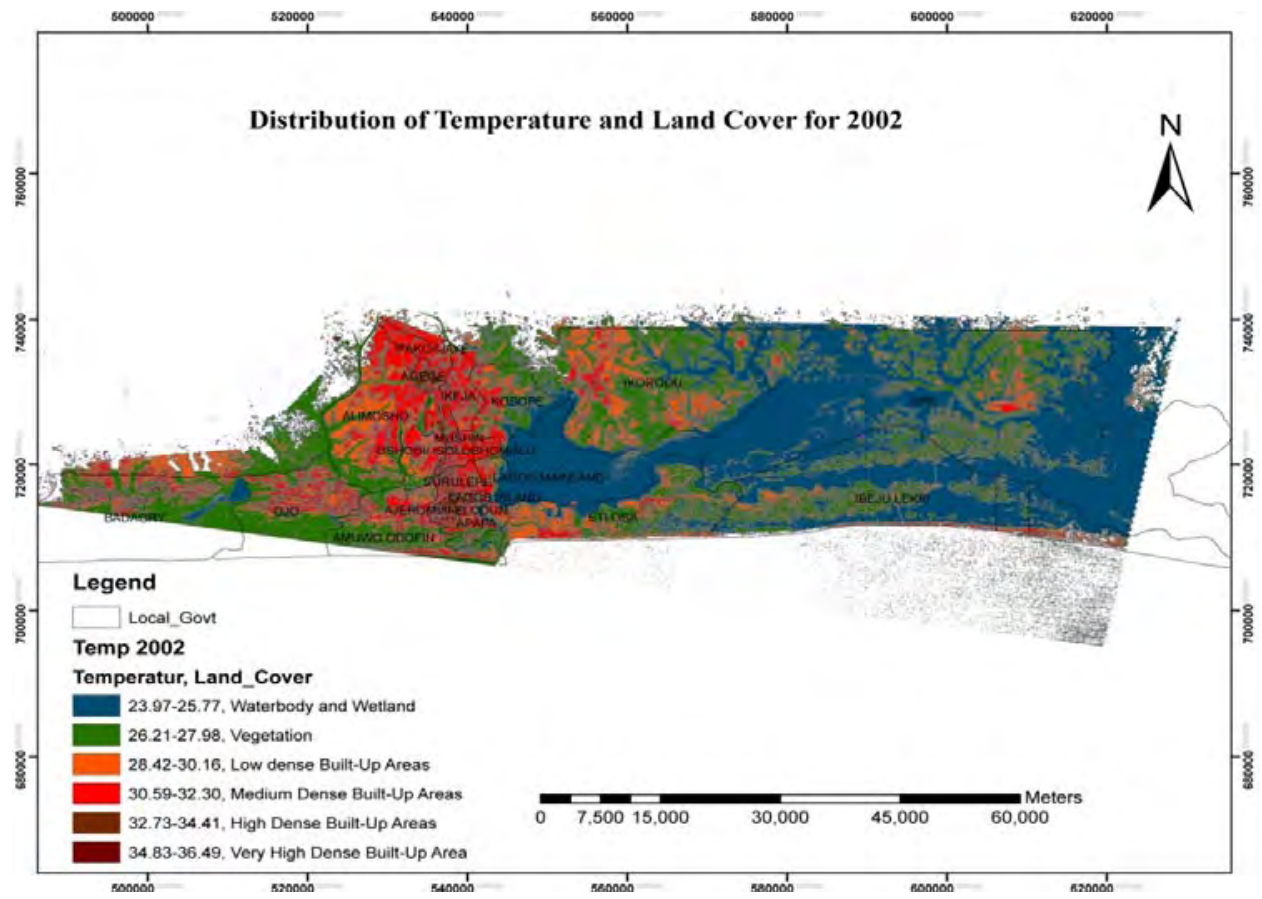

Figure 4: The relationship between the temperature and Land Cover over the Lagos for 2002 


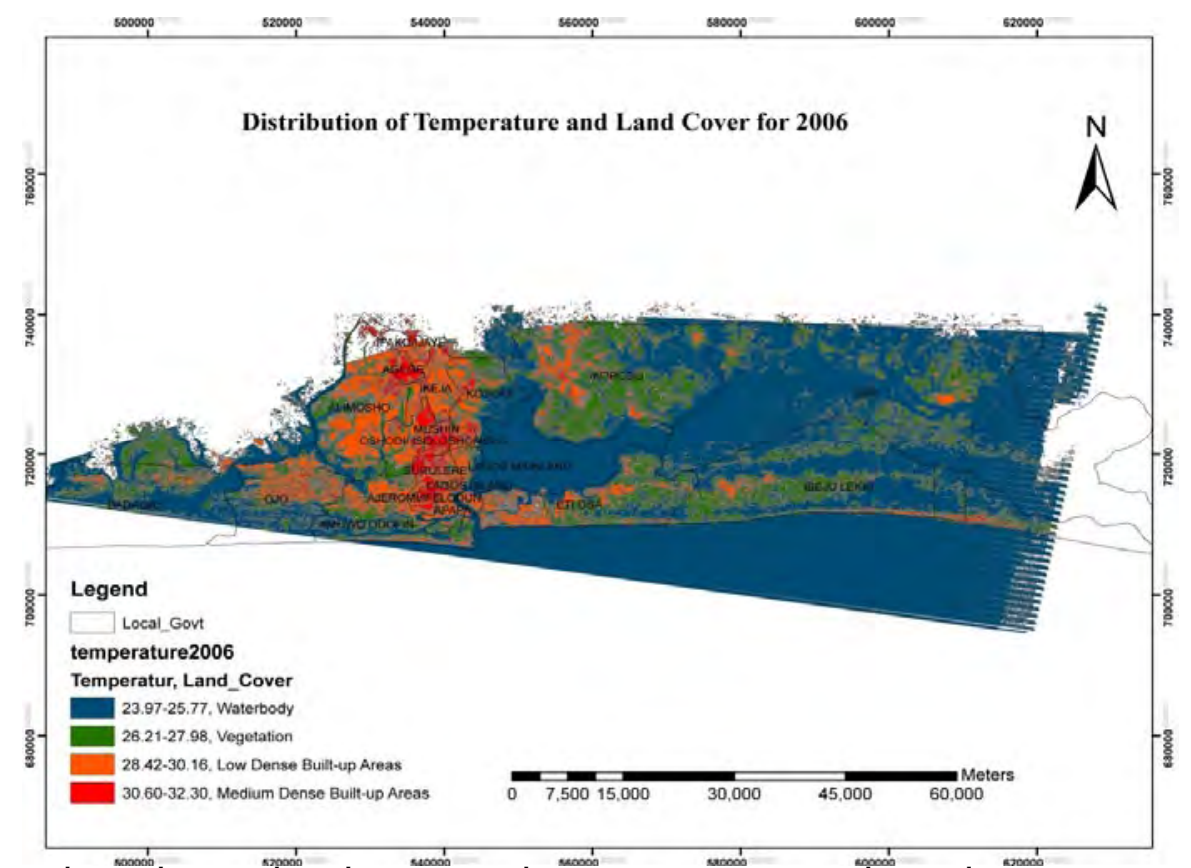

Figure 5: The relationship between the temperature and Land Cover over the Lagos for 2006

Table 2: Temperature values of selected features across different local government areas (LGAs) of Lagos for 1984, 2002 and 2006.

\begin{tabular}{|c|c|c|c|c|c|}
\hline \multirow[t]{2}{*}{ COORDINATES } & \multicolumn{3}{|c|}{ TEMPERATURE VALUE ( $\left.{ }^{\circ} \mathrm{c}\right)$} & \multirow[t]{2}{*}{$\begin{array}{l}\text { FEATURE } \\
\text { TYPE }\end{array}$} & \multirow[t]{2}{*}{$\begin{array}{l}\text { LOCAL GOVT } \\
\text { AREA }\end{array}$} \\
\hline & 1984 & 2002 & 2006 & & \\
\hline $538445.1390,713896.1250$ & 32.3027 & 32.2727 & 30.5915 & BUILT-UP & Ajeromi/ffelodun \\
\hline $536753.6050,712529.3650$ & 32.3027 & 33.1503 & 31.0214 & BUILT-UP & " \\
\hline 538025.6390 .712272 .2520 & 32.3027 & 33.1503 & 31.0214 & BUILT-UP & " \\
\hline $539155.3740,714163.6230$ & 31.877 & 31.45 & 32.727 & VEGETATION & " \\
\hline $536100.2150,713605.7240$ & 27.101 & 27.543 & 29.294 & VEGETATION & " \\
\hline $537335.5620,715266.1370$ & 29.294 & 29.728 & 31.45 & VEGETATION & \\
\hline $537487.3920,711578.0160$ & 28.421 & 27.5427 & 26.214 & WATERBODY & \\
\hline $538628.8800,711468.5580$ & 27.5427 & 27.1013 & 25.768 & WATERBODY & \\
\hline $538581.9690,712281.6730$ & 29.2935 & 29.7275 & 28.421 & WATERBODY & \\
\hline $542772.0400,721668.8620$ & 31.4498 & 31.8769 & 30.5915 & BUILT-UP & Shomolu \\
\hline $544382.1630,721628.2710$ & 26.214 & 25.768 & 24.871 & $\begin{array}{l}\text { WATER } \\
\text { BODY }\end{array}$ & 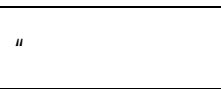 \\
\hline $540920.3690,720988.1010$ & 31.0214 & 30.5915 & 30.1602 & BUILT-UP & " \\
\hline $543520.8770,723378.530$ & 31.0214 & 31.8769 & 31.4498 & BUILT-UP & " \\
\hline $541296.4810,723186.0910$ & 27.543 & 27.101 & 29.294 & VEGETATION & $"$ \\
\hline $540947.6000,724378.7910$ & 27.1013 & 28.421 & 27.5427 & VEGETATION & \\
\hline $541519.4390,722989.5390$ & 27.1013 & 28.858 & 28.421 & VEGETATION & \\
\hline $544378.6360,722186.2400$ & 26.214 & 26.6584 & 25.768 & WATERBODY & \\
\hline $544923.2450,721382.9420$ & 26.214 & 24.8713 & 25.768 & WATERBODY & \\
\hline $543294.2260,730031.1140$ & 30.1602 & 31.8769 & 30.1602 & BUILT-UP & Kosofe \\
\hline $547198.2220,727989.3700$ & 24.421 & 25.768 & 25.768 & VEGETATION & Kosofe \\
\hline $541478.9450,733056.5830$ & 30.5915 & 31.8769 & 31.0214 & BUILT-UP & " \\
\hline $544461.1930,723591.1860$ & 30.5915 & 31.8769 & 31.0214 & BUILT-UP & " \\
\hline $549405.1340,727739.7190$ & 24.871 & 25.768 & 24.421 & $\begin{array}{l}\text { WATER } \\
\text { BODY }\end{array}$ & " \\
\hline
\end{tabular}




\begin{tabular}{|c|c|c|c|c|c|}
\hline $550944.3420,728215.8320$ & 24.8713 & 24.8713 & 25.3204 & WATERBODY & \\
\hline $545282.3920,721948.7880$ & 25.768 & 24.8713 & 25.3204 & WATERBODY & \\
\hline $542473.0270,732451.4900$ & 25.768 & 25.768 & 25.768 & VEGETATION & \\
\hline $547400.2210,726011.5620$ & 25.768 & 26.6584 & 25.768 & VEGETATION & \\
\hline $535534.5440,728728.3360$ & 28.858 & 27.101 & 27.101 & VEGETATION & IKEJA \\
\hline $540257.1800,734216.6040$ & 29.7275 & 31.4498 & 30.5915 & BUILT-UP & " \\
\hline $537513.4180,729388.9730$ & 31.0214 & 31.8769 & 30.1602 & BUILT-UP & " \\
\hline $539805.6750,725117.0410$ & 31.4498 & 30.5915 & 32.7272 & BUILT-UP & “ \\
\hline $540917.0720,727513.4910$ & 26.6584 & 25.768 & 25.768 & VEGETATION & \\
\hline $538867.9330,735432.1940$ & 26.214 & 27.5427 & 27.5427 & VEGETATION & \\
\hline $534700.1950,733487.2500$ & 31.0214 & 33.5721 & 30.5915 & BUILT-UP & Agege \\
\hline $536297.8280,731577.0360$ & 31.4498 & 33.5721 & 30.5915 & BUILT-UP & " \\
\hline $534236.3610,734630.0770$ & 30.16 & 28.421 & 31.877 & VEGETATION & " \\
\hline $534839.1200,730361.4460$ & 31.4498 & 32.7272 & 31.0214 & BUILT-UP & " \\
\hline $533332.9930,732649.4200$ & 27.5427 & 30.1602 & 28.858 & VEGETATION & " \\
\hline $534126.7340,734566.6120$ & 29.2935 & 31.0214 & 30.1602 & VEGETATION & " \\
\hline $555871.0210,731345.7520$ & 31.4498 & 33.1503 & 31.4498 & BUILT-UP & Ikorodu \\
\hline $574149.3840,736897,5920$ & 30.1602 & 31.4498 & 30.1602 & BUILT-UP & " \\
\hline $551492.2140,727420.1660$ & 24.871 & 25.32 & 24.871 & $\begin{array}{l}\text { WATER } \\
\text { BODY }\end{array}$ & " \\
\hline $568308.6810,732892.5090$ & 25.32 & 25.32 & 24.871 & VEGETATION & “ \\
\hline COORDINATES & \multicolumn{3}{|c|}{ TEMPERATURE VALUE $\left({ }^{\circ} \mathrm{c}\right)$} & $\begin{array}{l}\text { FEATURE } \\
\text { TYPE }\end{array}$ & $\begin{array}{l}\text { LOCAL GOVT } \\
\text { AREA }\end{array}$ \\
\hline $566419.5150,725793.9130$ & 27.9826 & 31.8769 & 31.0214 & BUILT-UP & " \\
\hline $550319.1810,730534.3300$ & 24.8713 & 26.214 & 25.3204 & VEGETATION & $"$ \\
\hline $568554.8380,732840.4780$ & 25.3204 & 25.3204 & 25.3204 & VEGETATION & $"$ \\
\hline $560161.4590,722521.7010$ & 25.768 & 25.768 & 25.768 & WATERBODY & $"$ \\
\hline $551173.3100,729594.7880$ & 23.5143 & 24.8713 & 25.3204 & WATERBODY & $"$ \\
\hline $543444.4170,713519.6090$ & 31.4498 & 31.4498 & 30.1602 & BUILT-UP & Lagos Island \\
\hline $544282.3030,714418.3610$ & 26.214 & 25.768 & 25.768 & $\begin{array}{l}\text { WATER } \\
\text { BODY }\end{array}$ & " \\
\hline $544812.3880,712611.3660$ & 30.1602 & 29.7275 & 28.858 & BUILT-UP & “ \\
\hline $543108.0300,714551.1950$ & 31.4498 & 30.1602 & 30.1602 & BUILT-UP & " \\
\hline $541679.0790,713900.4630$ & 26.214 & 25.3204 & 25.3204 & WATERBODY & " \\
\hline $543335.4370,712439.7930$ & 26.6584 & 25.768 & 25.768 & WATERBODY & " \\
\hline MEAN & 28.39589 & 28.85765 & 28.37168 & & \\
\hline
\end{tabular}

Table 3: Average values of each feature for the 3 periods in different LGAs

\begin{tabular}{|c|c|c|c|c|c|c|c|c|c|}
\hline Location & Built- & Jp Are & & Veget & Cover & & Water & ody & \\
\hline & 1984 & 2002 & 2006 & 1984 & 2002 & 2006 & 1984 & 2002 & 2006 \\
\hline Ajeromi & 32.3 & 32.9 & 30.9 & 29.4 & 29.6 & 31.2 & 29.4 & 28.1 & 26.8 \\
\hline Somolu & 31.2 & 31.5 & 30.7 & 27.2 & 28.1 & 28.4 & 26.2 & 25.8 & 25.5 \\
\hline Ikeja & 30.5 & 31.9 & 30.7 & 27.2 & 26.8 & 26.8 & $* \star *$ & $* * *$ & 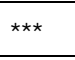 \\
\hline Kosofe & 30.7 & 31.3 & 31.2 & 25.3 & 26.1 & 25.8 & 25.2 & 25.2 & 25.0 \\
\hline Agege & 31.3 & 33.3 & 30.7 & 29.0 & 29.9 & 30.3 & $\star \star \star *$ & $\star \star \star *$ & 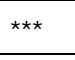 \\
\hline Ikorodu & 29.9 & 32.2 & 30.9 & 25.2 & 25.6 & 25.2 & 24.7 & 25.3 & 25.3 \\
\hline Lagos Island & 31.0 & 30.5 & 29.7 & $\star \star \star$ & $\star \star \star *$ & 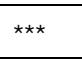 & 26.4 & 25.6 & 25.6 \\
\hline
\end{tabular}

(*** imply almost no water body and vegetal cover in the location) 


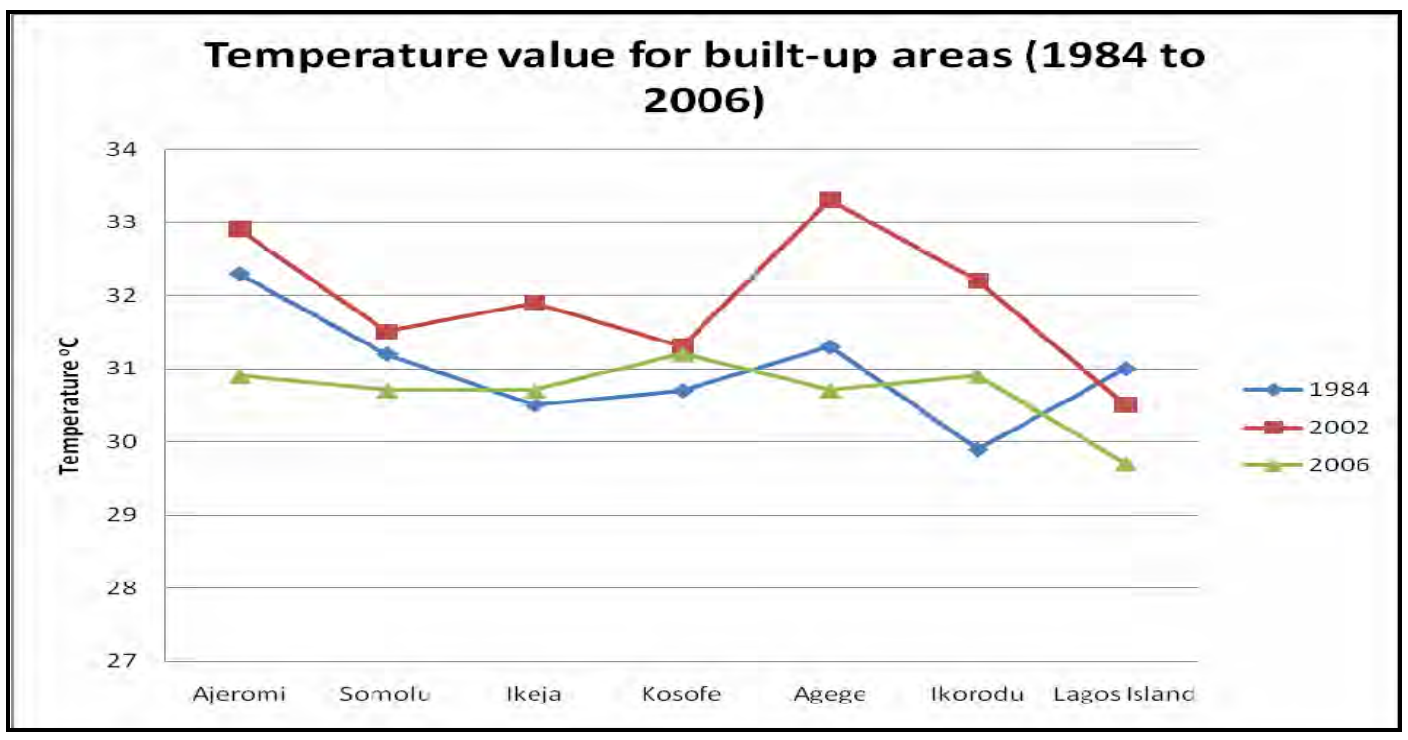

Figure 6: Temperature Variation for Built-Up Areas 1984, 2002 and 2006

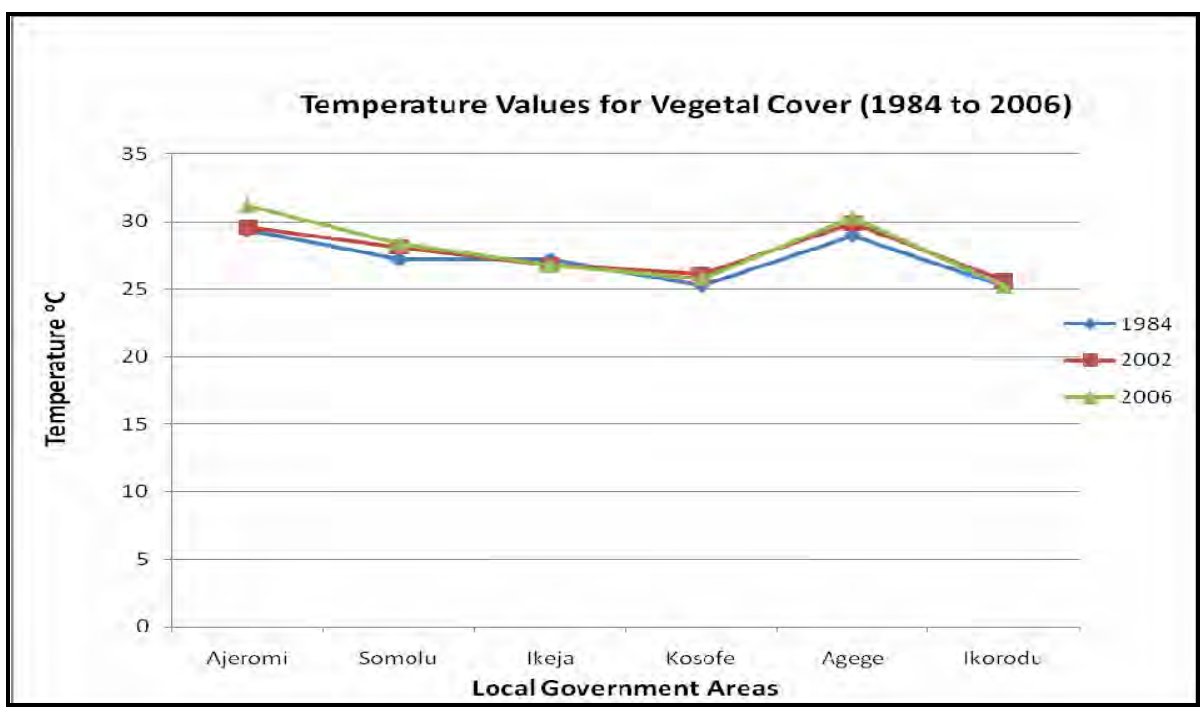

Figure 7: Temperature Variation for Vegetal Cover 1984, 2002 and 2006

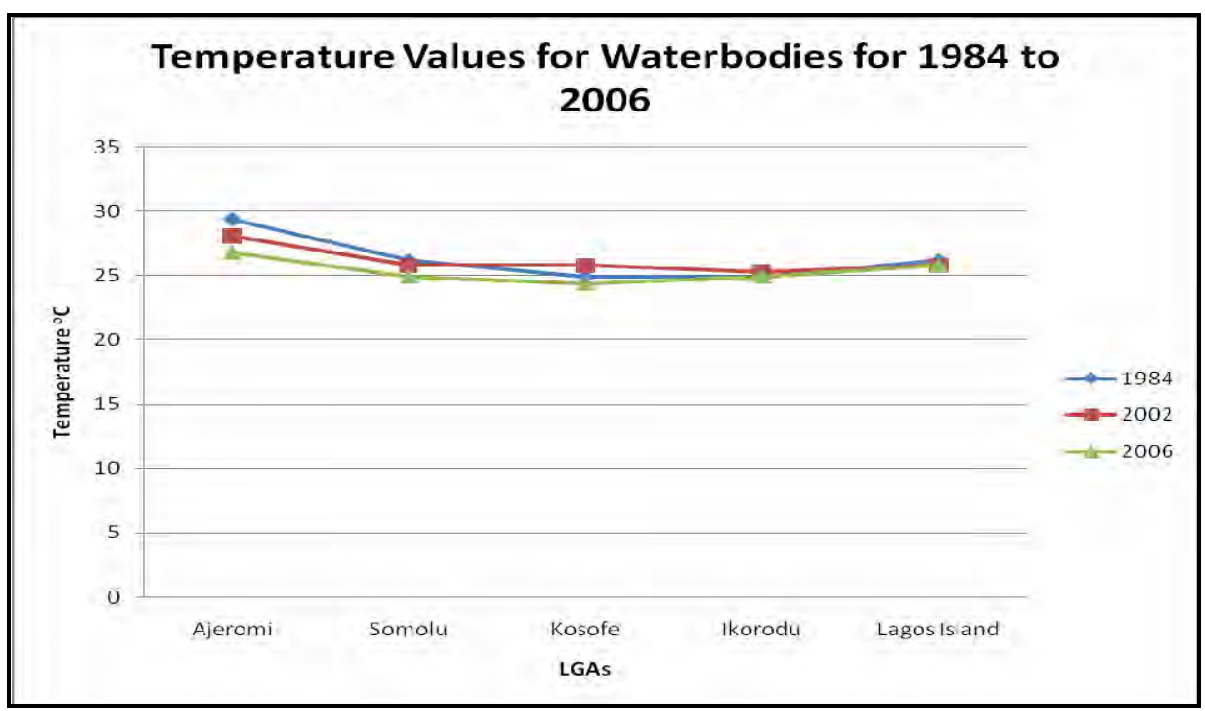


Figure 8: Temperature Variation for Water bodies 1984, 2002 and 2006

Temperature values of selected features across different local government areas (LGAs) of Lagos State for 1984, 2002 and 2006 was determined (Table 2). On the average (Table 3 \& 4), from 1984 to 2002, there is a significant increase in the temperature values. However, in 2006 the temperature decreases significantly below 2002 temperatures in all LGAs. This variation could be attributed to the economic crisis/power outage in Nigeria which left manufacturing companies closed down between 2002 and 2006. This shows that there is relationship between number of industries and industrial enhanced temperature. Figure 7 shows distribution of built up areas and Industrial Locations within Lagos. The industrial locations are spread across the built up areas within Lagos, this consequently explains the reason for the high temperature values of the built up areas because of the increase in carbon dioxide content being released into the environment which is a cause for the increase in temperature. Areas like Agege, Mushin, Ajeromi Ifelodun and parts of Ifako Ijaiye Local government areas with high temperature values clearly depict population enhanced temperature while Badagry Local Government with very high temperature value is as a result of industries enhanced temperature (figures 10-12).

Clearly, Lagos is a mega city with concentration of industries. The distribution of industries built up areas will definitely have impact on the LST of the State. Figure 9 reveals that low dense built up areas has the lowest temperature values $\left(28^{\circ} \mathrm{C}-30^{\circ} \mathrm{C}\right)$ against the very high dense built up areas with temperature range of $34^{\circ} \mathrm{C}$ to $36^{\circ} \mathrm{C}$. Relationship between area covered and temperature is displayed in figure 13 .

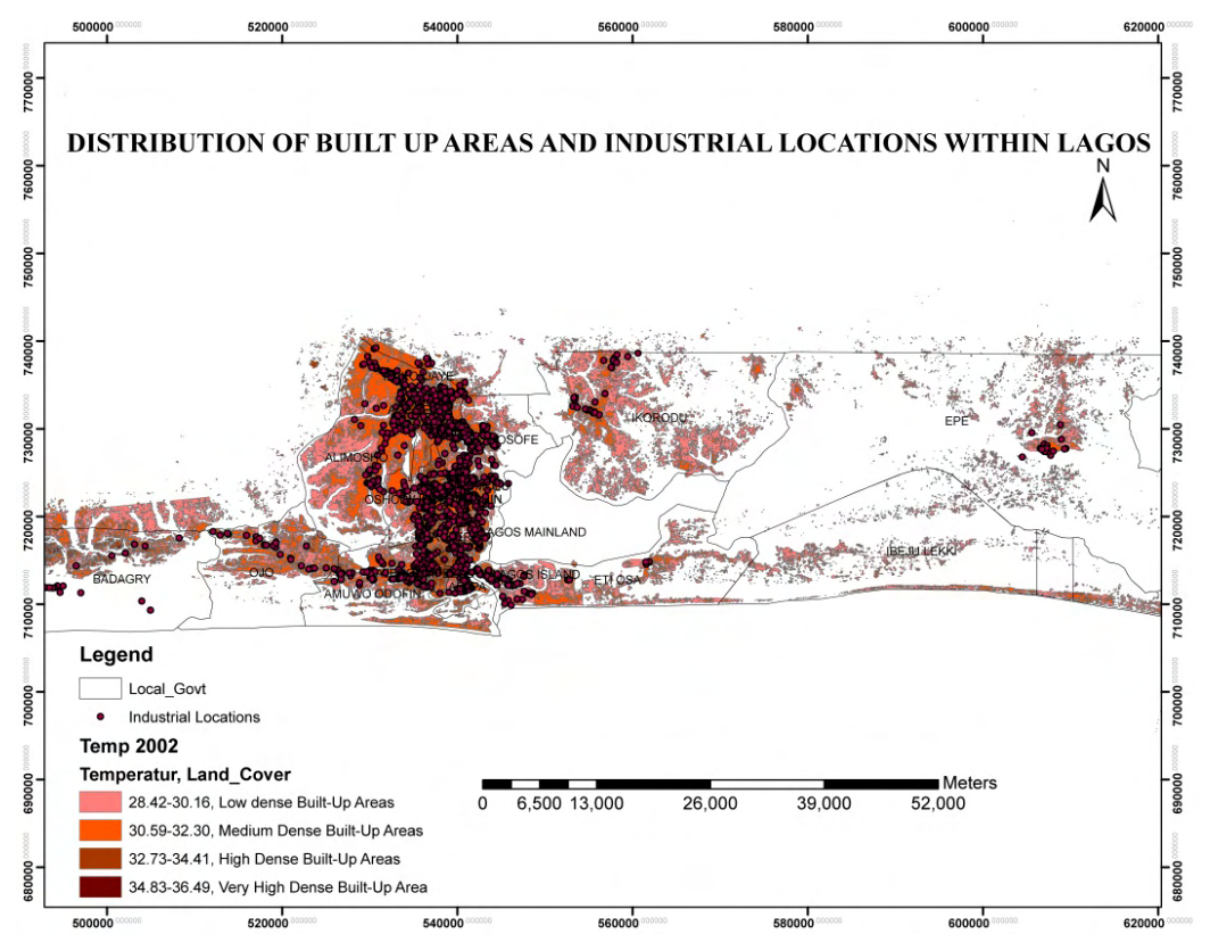

Figure 9: Distribution of built up areas and Industrial Locations within Lagos 
Table 4: Differences in Temperature between the 3 years in Numerical Term

\begin{tabular}{|c|c|c|c|c|c|}
\hline \multirow{3}{*}{ Land Cover } & \multicolumn{3}{|c|}{ LST } & \multirow{2}{*}{\multicolumn{2}{|c|}{ Change $\left({ }^{0} \mathrm{C}\right)$}} \\
\hline & $\left({ }^{0} \mathrm{C}\right)$ & & & & \\
\hline & 1984 & 2002 & 2006 & $\begin{array}{ll}(' 84 & - \\
\prime & -\end{array}$ & $\begin{array}{l}\text { ('02 } \\
\text { '06) }\end{array}$ \\
\hline Built-Up & 31.0 & 31.9 & 30.8 & 0.9 & -1.1 \\
\hline Vegetal Cover & 27.2 & 27.7 & 28.0 & 0.5 & 0.3 \\
\hline Water bodies & 26.4 & 26.0 & 25.6 & -0.4 & -0.4 \\
\hline Mean of Mean & 28.2 & 28.5 & 28.1 & 0.3 & -0.4 \\
\hline
\end{tabular}

(- imply decrease in temperature value)

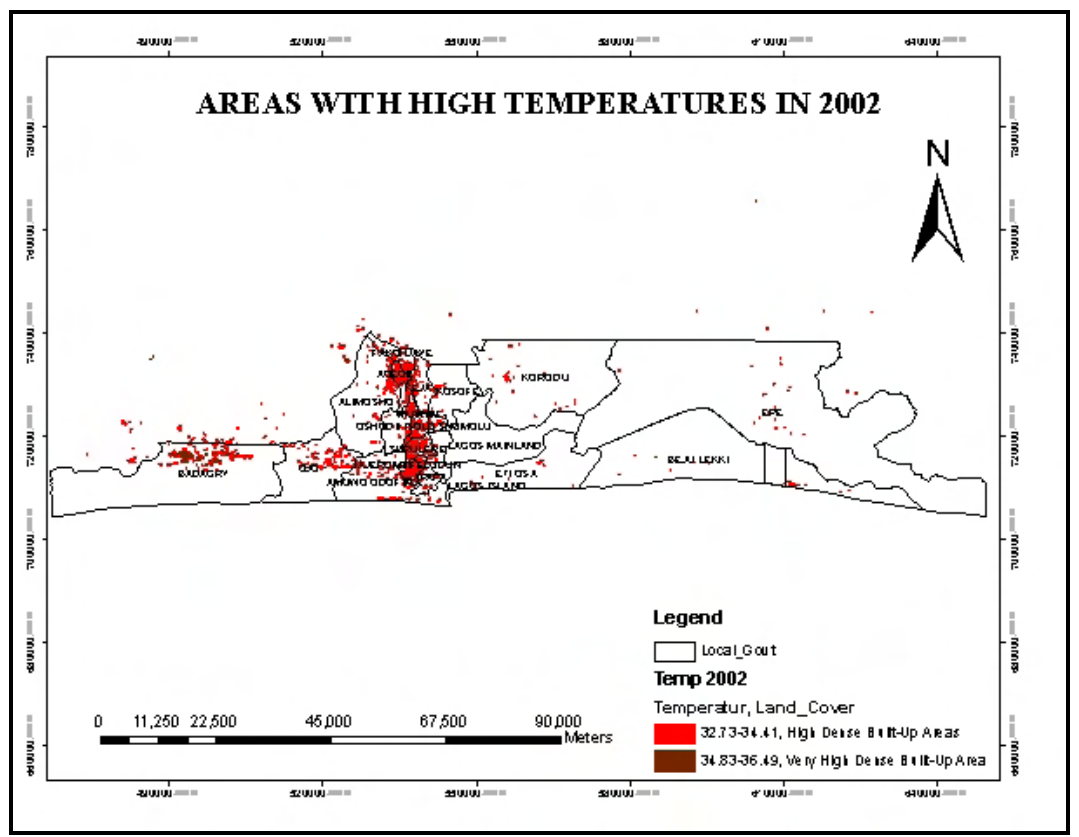

Figure 10: Agege, Ajeromi- Ifelodun, Ikeja, and Mushin LGA with High temperature values in 2002. 


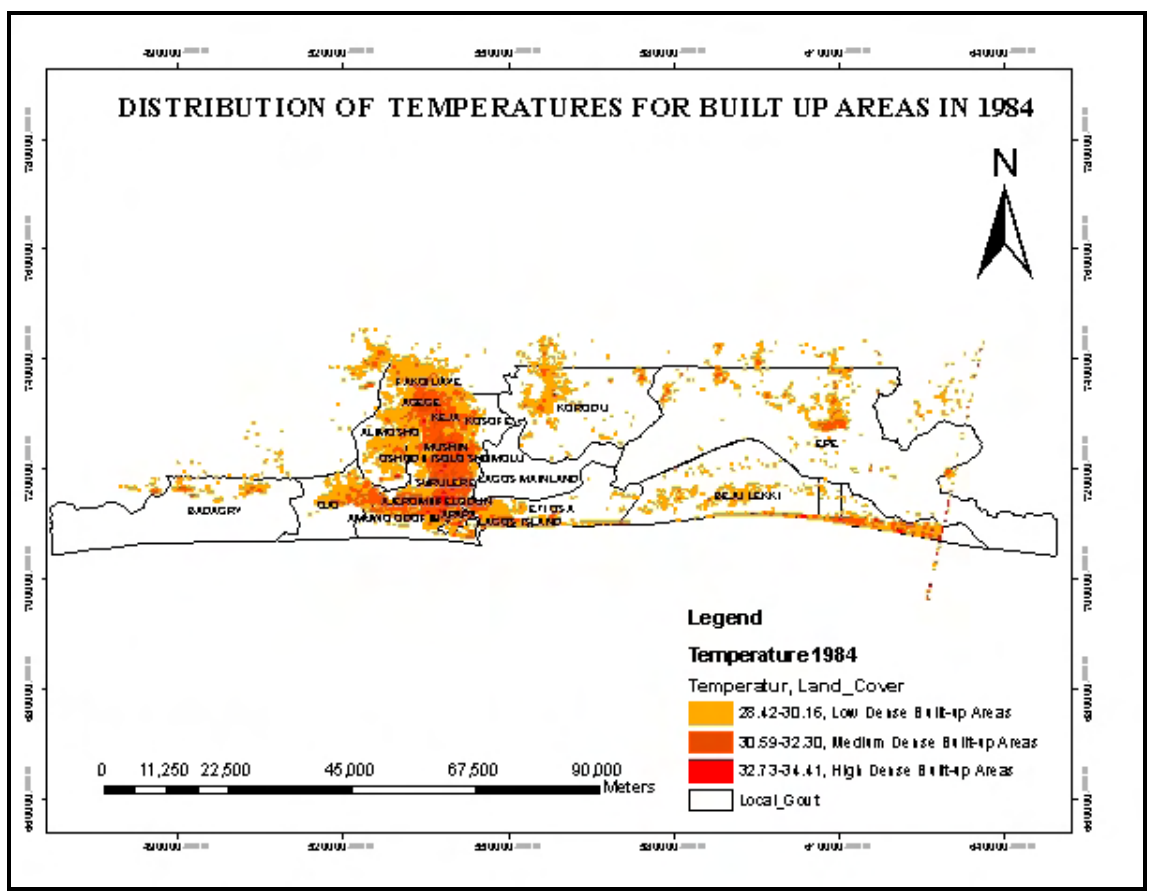

Figure 11: The spread of the temperature range values for built-up areas across Lagos State in 1984

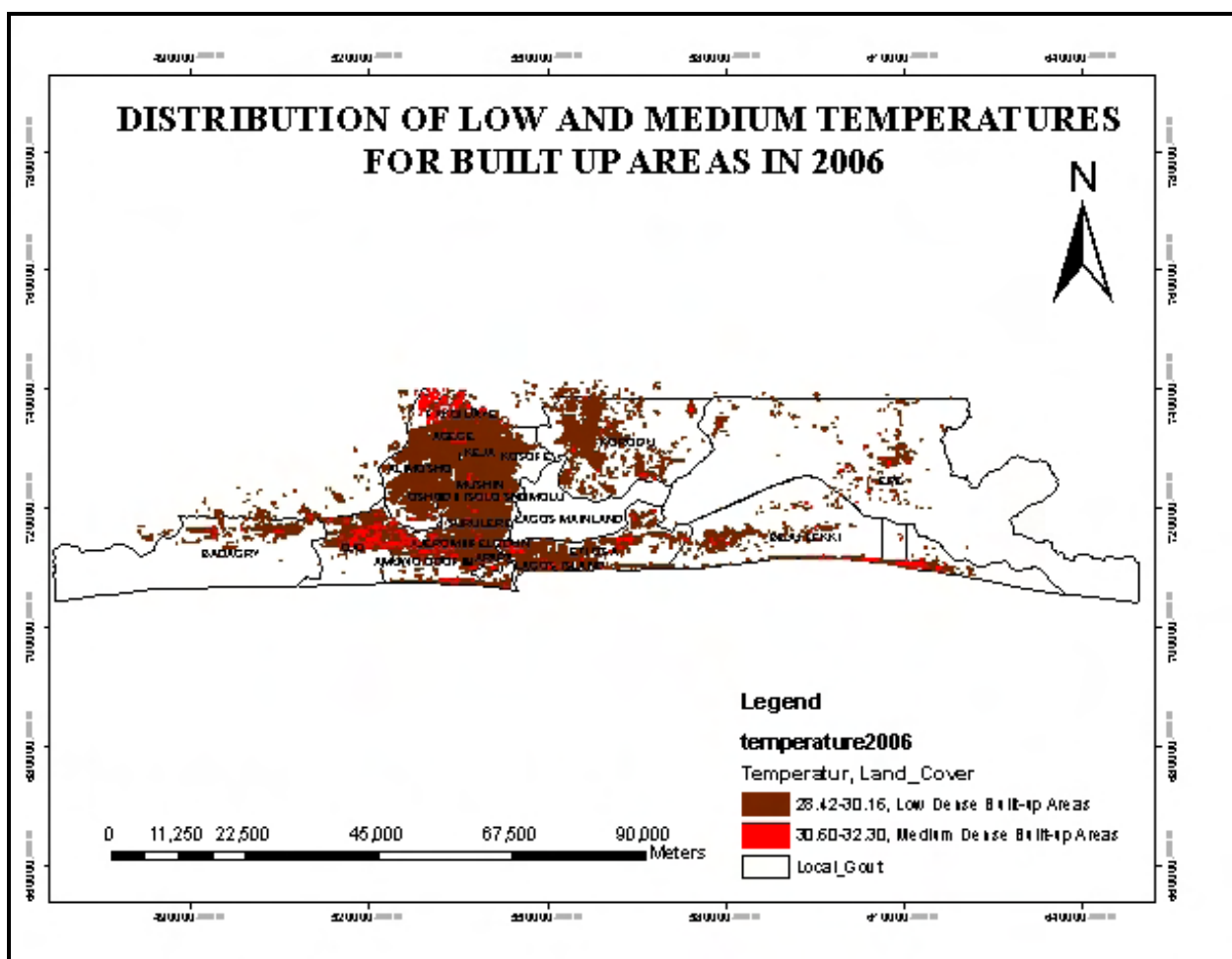

Figure 12: Distribution of Low and Medium temperature values for built-up areas across Lagos State in 2006. 


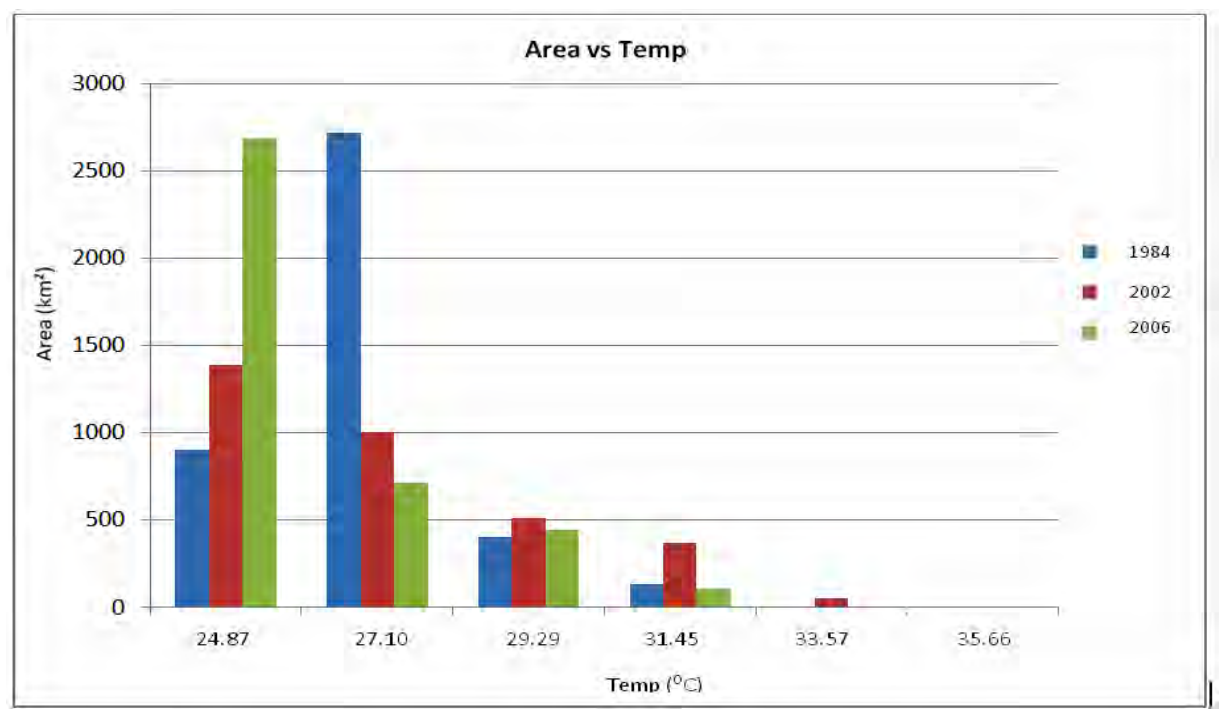

Figure 13: Relationship between the area covered and the temperature

\section{Conclusion}

Landsat imageries have been used to determine and extract temperature information of locations within the imagery. A comparative analysis has also been carried out for different years to show variations in temperature and its subsequent effect on the environment. The study has shown that:

- Temperature values can be extracted for any location from the satellite imagery

- Population increase and Industrialization in the built-up areas are major factors that increase the temperature of any area.

- Environmental factors like cloud cover, wind, amount of rainfall, wetland have a way of causing variation in the temperature values.

- Temperature values extracted can be used to carry out LandCover classification

- The mean LST for the 3 years considered are $28.40^{\circ} \mathrm{C}, 28.86^{\circ} \mathrm{C}$ and $28.37^{\circ} \mathrm{C}$ for 1984, 2002 and 2006 respectively (Table 2).

- While the LST of water bodies decreased with a constant value of $0.4^{\circ} \mathrm{C}$ (1984-2002) and from (2002 - 2006), the mean LST of vegetal cover was seen to appreciate by $0.5^{\circ} \mathrm{C}$ and $0.3^{\circ} \mathrm{C}(1984-2002)$ and (2002 - 2006) respectively.

\section{Recommendation}

There is a significant increase in the temperature values from 1984 to 2002. However, in 2006 the temperature decreases significantly below 2002 temperatures in all LGAs. This variation could be attributed to the economic crisis/power outage in Nigeria which left manufacturing companies out of production/manufacturing between 2002 and 2006. This shows that there is relationship between number of industries, carbon production and industrial enhanced temperature. A further study on modelling this relationship mathematically is therefore recommended. 


\section{References}

Artis, D. A., and Carnahan,W. H. (1982). Survey of Emissivity Variability in Thermography of Urban Areas. Remote Sensing of Environment, 12, 313-329.

Balling, R. C and Brazell, S. W. (1988). High resolution surface temperature patterns in a complex urban terrain, Photogrammetric Engineering \& Remote Sensing, 54, 1289 - 1293.

Carson, T. N, Gillies, R. R and Perry, E. M, (1994). A method to make use of thermal infrared temperature and NDVI measurements to infer surface soil water content and fractional vegetation cover, Remote Sensing of Environment, 9, $161-173$.

David A. R. (2008). A re-interpretation of Landsat TM data on Chernobyl. International Journal of Remote Sensing. Volume 10, Issue 8, 1989, Pages 1423 - 1427.

Gallo K. P, Mcnab A. L, Karl T. R, brown J. F, Hood J. J, and Tarpley J. D, (1993). The use of NOAA AVHRR data assessment of the urban heat island effect, Journal of Applied Meteorology, 32, 899 - 908.

Javed M., Yogesh, K. and Bharath B. D., (2008). Estimation of land surface temperature over Delhi using Landsat-7 ETM+. J. Ind. Geophys. Union. July, 2008. Vol.12, No.3, pp.131-140.

Jiansheng, Y. and Wang Y. Q. (2009). Estimation of Land Surface Temperature using Landsat-7 ETM + Thermal Infrared and Weather Station Data. Department of Natural Resources Science, University of Rhode Island. Kingston, RI 02881, USA

Jiménez-Muñoz, J. C., Sobrino, J. A. (2003). A generalized single-channel method for retrieving land surface temperature from remote sensing data. Journal of Geophysical Research, 108, doi: 10.1029/2003JD003480

Jinqu Zhang, Yunpeng Wang and Yan Li (2006). A C ++ Program for retrieving land surface temperature from the data of Landsat TM / ETM + band 6, Computers \& Geosciences, 32, $1796-1805$.

Kalnay, E. and Cai, M. (2003). Impact of urbanization and land use on climate change. Nature, 423, 528 - 531.

Landsat Project Science Office, (2002). Landsat 7 Science data user's handbook. Goddard Space Flight Center, NASA.

Lovholt, F., Bungum, H., Harbitz, C. B., Glimsal, S., Lindholm, C. D., and Pedersen, G. (2006). "Earthquake related tsunami hazard along the western coast of Thailand." Natural Hazards and Earth System Sciences. Vol. 6, No. 6, 979-997. November 30, 2006.

Markham, B. L. and Barker, J. K. (1985). Spectral characteristics of the LANDSAT Thematic Mapper sensors. International Journal of Remote Sensing, 6, 697-716.

Millington A. C., Tansey K. T. and Adepoju M. O. (2006) Land Use/Land Cover Change Detection In Metropolitan Lagos (Nigeria): 1984-2002; ASPRS 2006 Annual Conference Reno, Nevada May 1-5. 
Mustard J. F., Carney M. A. and Sen, A. (1999). The Use of Satellite Data to Quantify Thermal Effluent Impacts. Estuarine, Coastal and Shelf Science (1999) 49, 509-524.

Oke, T. R. (1982) The energetic basis of the urban heat island. Quarterly Journal of the Royal Meteorological Society 108, 1-24.

Qin. Z, Karnieli A. and Berliner. P., (2001). A mono-window algorithm for retrieving land surface temperature from Landsat TM data and its application to the IsraelEgypt border region, International Journal of Remote Sensing, 22 (18), 3719 - 3746.

Ramachandra T. V. and Uttam K, (2010). Greater Bangalore: Emerging Urban Heat Island. Energy \& Wetlands Research Group. Centre for Ecological Sciences, Indian Institute of Science, Bangalore - 560 012, INDIA

Sobrino J. A, Juan C. J and Leonardo P., (2004). Land surface Temperature Retrieval from LANDSAT TM 5. Remote Sensing of Environment 90 (2004) 434-440.

Srivastava P. K., Majumdar T. J. and Amit K. B. (2009). Surface temperature estimation in Singhbhum Shear Zone of India using Landsat-7 ETM+ thermal infrared data. Available online 3 February 2009. Retrieved from: linkinghub.elsevier.com/retrieve/pii/S0273117709000714.

Voogt. J. A and Oke. T. R, (2003). Thermal remote sensing of urban climates, Remote Sensing of Environment, 86, $370-384$.

UN (2007). Urban Agglomeration Report. United Nations Department of Economic and Social Affairs (Population Division), 2007.

Web: http://wgbis.ces.iisc.ernet.in/energy

Weng. Q, (2003). Fractal analysis of satellite detected urban heat island effect, Photogrammetric Engineering \& Remote Sensing, 69 (5), 555 - 566.

Weng. Q, Lu. D, Schubring. J, (2004) Estimation of land surface temperature vegetation abundance relationship for urban heat island studies, Remote Sensing of Environment, 89 (4), $467-483$.

Zhang, Y. Wang, Z. Wang (2007). Change analysis of land surface temperature based on robust statistics in the estuarine area of Pearl River (China) from 1990 to 2000 by Landsat TM/ ETM + data, International Journal of Remote Sensing, 28(10), 23832390. 